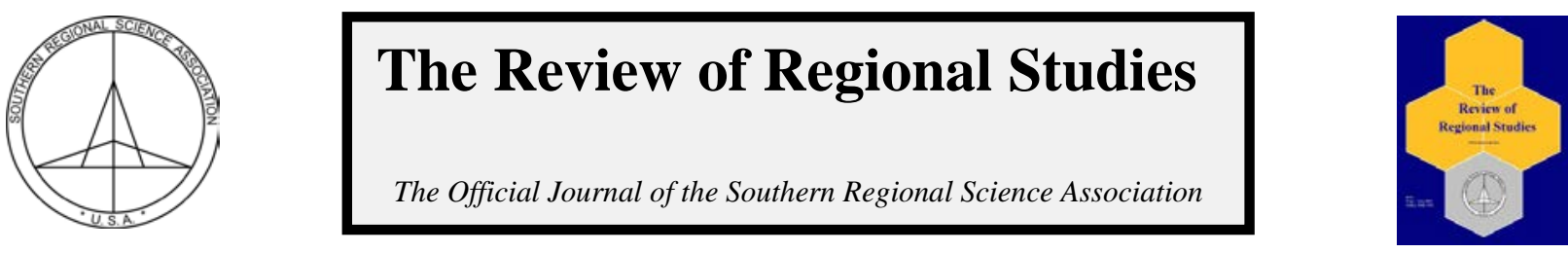

\title{
Income Inequality and Economic Development Incentives in US States: Robin Hood in Reverse?*
}

\author{
Jia Wang ${ }^{\mathrm{a}}$, Stephen E. Ellis ${ }^{\mathrm{b}}$, and Cynthia L. Rogers ${ }^{\mathrm{c}}$ \\ ${ }^{a}$ Department of Economics and Finance, University of Dayton, USA \\ ${ }^{b}$ Department of Philosophy, University of Oklahoma, USA \\ ${ }^{c}$ Department of Economics, University of Oklahoma, USA
}

\begin{abstract}
This paper explores the relationship between the rising use of economic development incentives (EDI) and rising income inequality within U.S. states. It extends the few papers which investigate state and local income inequality outcomes in the U.S. (Goetz et al., 2011; Shuai, 2015) in three important ways. First, it provides a normative argument for reducing inequality as a policy goal, an issue commonly ignored in empirical applications of inequality. Second, it discusses the channels through which EDI policy can influence equality outcomes in a regional context. Finally, it estimates panel data models for 41 states from 2000 to 2009 using direct measures of EDI and three common measures of income inequality: Gini, top 1 percent income share and top 10 percent income share. The results reveal positive and statistically significant relationships between the one-year lag of EDI values and the three inequality measures. Taken as a whole, the results are consistent with a reverse-Robin-Hood effect where more generous EDI use is associated with redistribution of income from the bottom 90 percent to the top 10 percent of the income distribution.
\end{abstract}

Keywords: economic development incentives, income inequality

JEL Codes: F58, H71, O15

Regional scientists commonly concern themselves with topics involving regional inequalities - why they occur and persist, how inequality may be reduced or what exacerbates it, and the impact of policy interventions. Regional inequalities fuel our research and its policy relevance.

-Olfert (2016, p. 201)

\section{INTRODUCTION}

Niño-Zarazúa, Roope, and Tarp (2016) argue that inequality is one of the most prominent political issues of this century. There is a growing awareness of rising inequality within regions despite declining inequality between regions: "the rise in national inequality has in general eclipsed the drop in global inequality, even though this drop is undeniable” (Bourguignon, 2015, p. 2). Most countries have experienced rising income inequality (Bastagli, Coady, and Gupta, 2012). The U.S. is no exception to this trend. Piketty, Saez, and Zucman (2016) find that the bottom half

\footnotetext{
* Acknowledgements. The authors thank Jacob Bundrik, Scott Eastman, Matt Mitchell, and Daniel Sutter for feedback and suggestions on drafts of this manuscript.

Wang is an Assistant Professor of Economics at the University of Dayton, Dayton, OH, 45469. Ellis is an Associate Professor of Philosophy and Rogers is a Professor of Economics at University of Oklahoma, Norman, OK. Corresponding Author: C.L. Rogers E-mail: crogers@ou.edu.
}

(C) Southern Regional Science Association 2018.

ISSN 1553-0892, 0048-749X (online)

www.srsa.org/rrs 
of the income distribution's share of national income fell from 20 percent in 1980 to 12 percent by 2014. ${ }^{1}$ In contrast, the share for the top 1 percent was exactly reverse, rising from 12 percent to 20 percent of the national income.

In this paper, we focus on the extent to which the use of economic development incentives (EDI) is related to income inequality within U.S. states. EDI are a mainstay of state and local economic development strategies in the U.S.: estimates of annual spending range from $\$ 45$ billion (Bartik, 2017) to $\$ 80$ billion (Story, 2012). EDI take various forms - including grants, tax exemptions, tax refunds, tax credits, and infrastructure investments - all of which lower a firm's cost of conducting business in a particular location. EDI are meant to influence business location decisions thereby creating a positive net benefit for the jurisdiction. Benefits are supposed to take the form of jobs, income, and state revenues: they can be direct or induced.

Despite the growing size and value of EDI programs, the empirical research fails to link EDI use with economic benefits in a conclusive manner (Bartik and Erickcek, 2014; Bartik, 2017). This raises concerns about how such programs impact income distribution within states: do such programs merely redistribute income from the average taxpayer to wealthy investors? The prisoners' dilemma aspect of incentive competition, where increasingly lucrative EDI are offered, erodes the potential for net gains even when the jurisdiction lands the firm (Ellis and Rogers, 2000). Wang (2017) finds evidence of state policy interaction in which state governments respond to EDI spending in other states. Goetz et al. (2011) find that race-to-the-bottom type policies such as targeted tax incentives and financial assistance are likely to harm growth and increase income inequality.

We explore the connection between the rising use and value of EDI and rising inequality within U.S. states. A key observation is that both EDI use and income inequality vary greatly by state, and both have grown over the past several decades (Williams, 2014; Frank, 2009; Leight, 2010; Bartik, 2017). Despite a vast literature on EDI growth impacts, few studies address the link between EDI use and state-level income inequality. We make several contributions. First, we address the normative aspect that is often skipped in the empirical literature: why reducing inequality should be a consideration for policies aimed at stimulating economic growth. Second, we discuss the channels through which EDI can influence income distribution. Third, using statelevel panel data for 41 states from 2000 to 2009, we extend previous empirical investigations (Goetz et al., 2011; Shuai, 2015) by including direct measures of EDI spending and investigating three conventional measures of income inequality in a regional context. The analysis reinforces concerns that EDI have inequality consequences whereby income is redistributed to the top income earners.

\section{REGIONAL SCIENCE LITERATURE}

Scholars attribute rising within-country inequality to many factors associated with globalization, the expansion of public holdings of companies, immigration policies, as well as tax policies that favor investors more than low wage workers (Diamond, 2016; Amadeo, 2017). Piketty, Saez, and Zucman (2016) note the role of rising income from investments in widening the gap and the small offsetting impact of income redistribution programs. Labor-saving technological

\footnotetext{
${ }^{1}$ See Figure 1, http://www.nber.org/digest/feb17/w22945.html which summarizes Piketty, Saez, and Zucman's analysis.

(c) Southern Regional Science Association 2018.
} 
advances also play a role. ${ }^{2}$ Such explanations, however, neglect important features of spatial heterogeneity and decentralized decision-making in the U.S.

The regional science literature has a strong tradition of investigating spatial aspects of economic outcomes (employment, income, etc.) as well as convergence across and within regions (see for instance Amos (1991) for a review of early empirical literature). Notably, regional models identify many factors that influence sub-national level growth trends, including location-specific conditions such as natural resource endowments, exogenous shocks, factor mobility (capital and labor), and the role of regional government policy. The extent of fiscal decentralization in the U.S. makes a regional approach particularly salient for understanding state-level income inequality. ${ }^{3}$ In 2015 , the U.S. federal government collected $\$ 3.4$ trillion in revenues. State governments collected about \$1.6 trillion in own source revenues and received \$508 billion from the federal government. Local governments collected a total of $\$ 1.2$ trillion including $\$ 650$ billion in own source revenues, $\$ 23$ billion from the federal government, and $\$ 500$ billion from state governments. ${ }^{4}$ Combined, state and local governments receive almost half (48.7 percent) of all revenues collected in the U.S. Accordingly, heterogeneity in the state and local revenue and expenditure policies are likely to influence income distribution outcomes across and within states.

The notion that regions compete via fiscal policy choices dates to Tiebout (1956) and Tullock (1971). Cognizant that households, businesses, and capital are mobile, local jurisdictions seek policies which satisfy the preferences of constituents or attract new constituents, businesses, or capital. Of course, not all constituents have an equal influence on policy choices. Public choice literature highlights concerns about rent-seeking motives and government favoritism (Mitchell, 2014). The increased use of EDI may also reflect increasingly successful lobbying by firms as they gain more experience and incorporate lobbying behavior into corporate management strategies (Drutman, 2015). Jansa and Gray (2017) argue that state governments may influence EDI policy directly via political influence or culturally via structural importance in the state economy. Gilens (2014) suggests that policies tend to favor the rich over the poor when preferences among income groups diverge.

\section{HOW SHOULD WE THINK ABOUT INCOME (IN)EQUALITY?}

In this section, we provide a normative argument for why income equality is a good thing, in itself. It is not merely a proxy for other value-relevant features; it is directly relevant to any overall normative analysis. A full examination of the normative issues is beyond the scope of this paper. Rather than attempting to establish the value of income equality from first principles; we appeal to plausible moral intuitions to establish that income equality is a good-making feature of outcomes. Further, we do not address the relative importance of income equality. It is certainly plausible that a normatively optimal policy would allow for a fair degree of income inequality. Our point is simply that more income equality is good, ceteris paribus.

Philosophers generally consider outcomes to be relevant to normative evaluation and recognize various good-making features of outcomes: self-guidance, material well-being, close personal relationships, knowledge, prestige, etc. Income is part of material well-being. Most of

\footnotetext{
2 “Technology, Not Globalization, Feeds Income Inequality,” The Wall Street Journal, July 24, 2008.

${ }^{3}$ Olfert (2015) notes the importance of decentralization in explaining regional variation in Canada.

${ }^{4}$ Bureau of Economic Analysis, National Income and Product Accounts, Federal Receipts: Table 3.2; State Receipts: Table 3.20; Local Receipts: Table 3.21.
}

(c) Southern Regional Science Association 2018. 
these features are valuable in virtue of their influence on particular individuals. If no specific individual benefits, then a feature like income would not be valuable at all. The distribution of benefit across individuals is also germane: a world where only a select few have access to decent incomes would be deficient quite apart from the overall level of aggregate income. Distribution over individuals is relevant: different distributions can have distinct values, even if they have, in some sense, the same 'amount' of each good-making feature.

Equality is a fundamental notion in contemporary moral thought. The basic view is that persons all have the same moral worth and so should, ceteris paribus, equally benefit from that status (Arneson, 2013). This egalitarian principle suggests that, whatever the features of the world that contribute to its moral worth, it is good for those features to be possessed or enjoyed equally by all in some relevant sense of 'possessed' and 'enjoyed.' Not only are outcomes with goodmaking features like income valuable, the equal moral worth of all people calls for more equality with respect to such features, at least ceteris paribus.

The foregoing discussion does not suggest that inequality at any level is simply unacceptable. In some circumstances, it is necessary to weigh offsetting values of multiple features. A certain degree of income inequality, for example, might be justified by gains to aggregate income and/or increased self-guidance resulting from connecting incomes with personal initiative. Exactly what sorts of tradeoffs are justified goes beyond the scope of this paper. Income equality remains inherently valuable even if other factors would carry more weight in policy choices.

Intuitions about the value of outcomes support the idea that income inequality is a normative concern. A family of views, however, holds that morality is purely a procedural issue for which no outcome is morally valuable. According to the "rights-based 'procedural' view" of ethics, behavior is normatively justified only if it follows the right rules (e.g., of ownership, transfer, etc.) (Sen, 1985). Equal application of the rules is required, but the results of actions are not germane to evaluation (see Williams, 1996). Consequently, income inequality is not a moral issue if material well-being itself is not a moral issue. ${ }^{5}$

Immanuel Kant is the most famous proponent of a purely procedural view of ethics. Whereas Kant is notoriously difficult to understand, it is clear that he wants to keep moral theory completely free from any empirical element (Kant, 1965). What is good without qualification, the good will, is independent of what it brings about (Kant, 1964). What counts as a right action is determined by a procedural test, universalization, that purports to disregard the values of outcomes (Kant, 1964).

Other procedural views are not so strict in disregarding outcomes. Robert Nozick grounds Libertarian side constraints (e.g., no involuntary redistribution of resources) in a need to keep some people from being sacrificed for the sake of others (Nozick, 1974). Once established, however, such side constraints apply without consideration of their purpose. Nozick takes them to be stringent (at least up to the point of catastrophic horror) even where the actual consequences of that stringency undermine the very considerations that ground the constraint in the first place (Nozick, 1974). David Schmidtz thinks likewise. Outcome considerations can ground moral rules, or at least our recognition of them, without limiting the application of those rules: "[a]n imperative may dictate an action without appealing to the action's role in serving the agent's purposes ...

\footnotetext{
${ }^{5}$ Many who hold a rights-based procedural view of ethics also oppose the practice of offering EDI. They do so on the grounds that EDI interfere with appropriate (usually voluntary, market-based) procedures and not because of any consequences they generate.
}

(c) Southern Regional Science Association 2018. 
[b]ut that does not preclude the possibility of the imperative having teleological support" (Schmidtz, 1995, p. 150). Thus, moral requirements are purely procedural despite their outcomeoriented justifications. Consider a simple example: If I tell my children to stay in the house when I am gone in order to keep them safe, they have a reason to stay in the house even when doing so is not conducive to their safety (e.g., in the event of an earthquake). In an economic context, a rule like respect property rights: do not interfere with the resources of others can be grounded in the outcome-oriented benefits of adopting the rule, but the rule still applies even where violating it would create better outcomes, all things considered.

Many consider the purely procedural normative perspective to be implausible because it fails to give proper consideration to valuable outcomes. Amartya Sen sees a dilemma for such a procedural view: either (1) rule following trumps outcome considerations, and "[i]t is not easy to understand why rules of ownership, transfer, etc. should have such absolute priority over the life and death of millions of people” or (2) rule following just is another consideration to be weighed in normative analysis, and so purely procedural accounts of morality are inadequate (Sen, 1985, p. 6). If we account for the normative force of procedures/rules by appealing to good outcomes, then the scope of those rules seems appropriately limited to circumstances where those outcomes obtain. If, for example, the point of property rights is to achieve certain ends then property rights are a concern just to the extent that those ends are at stake. As long as outcomes are admitted to be morally relevant, there is a case for the normative import of income equality.

To summarize the philosophic argument, concern about the propriety of EDI is not necessarily derived from concern about equality of incomes (or any other outcome). If equality of income is valuable, however, then the distributional effects of EDI are relevant policy considerations.

\section{CHANNELS LINKING EDI PROGRAMS WITH THE INCOME DISTRIBUTION}

Many scholars note the link between economic growth, income inequality, and policy strategies. Bonica et al. (2013) conclude that politics and policy have contributed to rising inequality. Price and Boushey (2014), among others, articulate the need for research focusing on the specific channels leading to inequality. As Brem, Durden, and Gaynor (1989) discuss, the general consensus is that inequality is influenced by changes in human capital, economic growth, and discrimination. Government programs could reduce inequality by fostering economic growth, enhancing human capital accumulation, particularly among the poor and minorities, and reducing discrimination (Brem, Durden, and Gaynor, 1989). Not all government programs, however, focus on equality goals.

Notably, jurisdictions use EDI to stimulate employment growth and/or attract capital investment to a jurisdiction. In theory, it is possible for a jurisdiction to offer an incentive to generate a net positive benefit from attracting a firm. A firm's location decision is influenced by the spatial distribution of both natural resource endowments and artificial factors, such as agglomeration factors, public infrastructure, private capital investments, and state and local fiscal policy. EDI have the potential to influence the location decision of a mobile firm, by either compensating for location-related cost differentials or increasing profitability among equally profitable locations. It is easy to see why people might think that offering EDI would be valuable for regional economic development, and why EDI are popular.

(c) Southern Regional Science Association 2018. 
The potential for negotiating EDI deals that actually generate net benefits, however, is fraught with practical challenges: there is a lot of uncertainty about the value of attracting a firm, a firm's costs and profits in a particular location, and competing offers (Patrick, 2014b). ${ }^{6}$ Incredibly, the majority of states do not perform ex ante analysis to inform EDI policy (Pew Center for the States, 2012). There are concerns about a winner's curse resulting from both poor costbenefit analysis and from rent-seeking on the part of firms in a competitive incentive bidding environment. As discussed in the reviews by Peters and Fisher (2004), Bartik and Erickcek (2014), Patrick (2014a), Wang (2016), and Bartik (2017), the extensive literature fails to find a consensus about the role of EDI in producing growth benefits along a number of dimensions. Less studied is the impact of EDI on equality goals.

The impact of EDI on income inequality is complex. Economic growth may lead to increased employment, wages, or occupational mobility which would lead to less income inequality (Partridge and Rickman, 2005; 2006). On the other hand, the distribution of the benefits is not clear. If the growth attracts new residents, then it is possible that the utility of the future residents comes at the expense of the utility of original residents (Partridge and Rickman, 2003). Further, as Mattera, Tarczynska, and LeRoy (2014) point out, many of the incentivized companies are well-known, low-wage employers. Thus, adding jobs to the low end of the distribution can lead to increased inequality via a direct composition effect. Dewar and Hagenlocker (1996), for example, find that Minnesota's low-interest loan program mainly created low-wage positions which probably lowered overall earnings per job in the state. Lynch and Zax (2011) fail to find a long term effect on earnings attributable to enterprise zones programs in Colorado. Hirasuna, and Pulver (1998) apply a computable general equilibrium model to show that subsidies to the traded services producing sector could lead to lower income inequality compared with subsidies to the manufacturing section. Persky, Felsenstein, and Carlson (2004) investigate direct and indirect effects using a job-chain approach which builds off traditional Leontief-type input-output models. They find that high-wage jobs are not likely to trickle down to lower groups. Notably, Hasanov and Izraeli (2011) and Price and Boushey (2014) highlight potential heterogeneous impacts of growth on different income groups.

EDI can also impact the income distribution via impacts on tax and spending policies. In a general equilibrium framework, taxes on households reduce the attractiveness of a region whereas expenditures on public goods can increase attractiveness (Goetz et al., 2011). A state government could decide to spend less on EDI and put the expenditure savings toward lower tax rates. Lower tax rates would generate more disposable income for individuals to spend as desired, making a region more attractive. ${ }^{7}$ Lower tax rates would also increase the region's attractiveness for current and potential new firms, holding public spending on factors that influence external costs constant.

The government might also substitute spending on EDI programs for more spending on public goods. To the extent that other public spending enhances income growth opportunities (e.g., job training programs for low income workers, education, etc.), EDI could negatively influence income equality. In addition, if EDI replace public spending on things that increase access to markets or vocational training, firms would incur higher external costs which could impact employment and wages. There is some evidence of state EDI spending crowding out public goods

\footnotetext{
${ }^{6}$ Patrick (2014b) discusses multiple mechanisms through which incentives competition induces bad deals which induce revenue shortfalls. She presents an incentive game framework which sheds light on mechanisms through which deals could be improved.

${ }^{7}$ We thank Jacob Bundrick for this point.
}

(C) Southern Regional Science Association 2018. 
expenditures: Wang (2016) finds a negative relationship between EDI spending and investment in some public goods categories, including education and corrections, which could influence inequality outcomes. If jurisdictions make bad deals which lead to revenue shortfalls, or suffer a winner's curse by over-bidding, then the opportunity costs could be even higher as governments reduce services or increase taxes to cover revenue shortfalls (Patrick, 2014b).

Given the inconclusive evidence about whether EDI achieve development goals, it is possible that EDI primarily redistribute large amounts of public funding to private entities with no offsetting benefits in employment, wages, or earnings. Notably, large corporations have been successful at negotiating multi-million and even billion dollar deals. It is estimated that at least 75 percent of cumulative disclosed EDI dollars have gone to just 965 large corporations (Mattera, 2014). According to Mattera, Tarczynska, and Leroy (2014), billionaires are linked to 99 firms that have been awarded more than $\$ 19$ billion in cumulative subsidies. They argue that EDI awards to large corporations contribute to the increasing income inequality in the U.S.

Of course, the impact on after-tax income distribution would need to consider tax incidence: if targeted individuals contribute more to the tax base used to support EDI, then the redistribution could be mostly among individuals at the top end of the distribution without much impact on the bottom, holding other factors constant. However, if EDI spending entails redistribution from low income earners to higher income earners, then the income gap could grow. ${ }^{8}$ This suggests the importance of considering various measures of income equality beyond the Gini coefficient which summarizes the entire distribution. As we discuss below, we pay particular attention to changes in income shares at the top end of the income distribution.

Only a few papers investigate the impact of state and local economic development policies on income inequality in the U.S. context. Shaui (2015) estimates county-level Gini coefficients, averaged over 2000 to 2010 as a function of business attraction variables attributable to economic development projects under the authority of the Virginia Economic Development Partnership. Importantly, Shuai finds that attracting manufacturing is associated with decreases in county-level income inequality but attracting professional and business services jobs has the opposite effect. However, it is not clear how well the estimates for Virginia would generalize to other states.

Goetz et al. (2011) present a general equilibrium framework to investigate dimensions of race-to-the-bottom (e.g., tax competition, EDI incentive bidding wars) and race-to-the-top (e.g. investment in human and social capital, innovation) economic development strategies. Using a cross-sectional analysis of states for the 2000 to 2006 period, they investigate the change in statelevel Gini coefficient expressed as a function of socio-economic variables as well as sets of key policy variables. The set of variables most related to our study is the combined economic freedom and EDI group. Due to data limitations, they use proxies for EDI spending: the state's share of all possible direct financial assistance programs and the share of all possible categories of tax incentive programs offered across the country. Thus, states using more categories of programs are presumed to spend more on EDI programs. Their results indicate that tax incentives and financial assistance programs were negatively correlated with employment growth.

\section{STATE EDI AND INEQUALITY TRENDS}

\footnotetext{
${ }^{8}$ We thank Matt Mitchell for making this point.

(C) Southern Regional Science Association 2018.
} 


\section{Figure 1: Inequality Trends: 50 State Means}

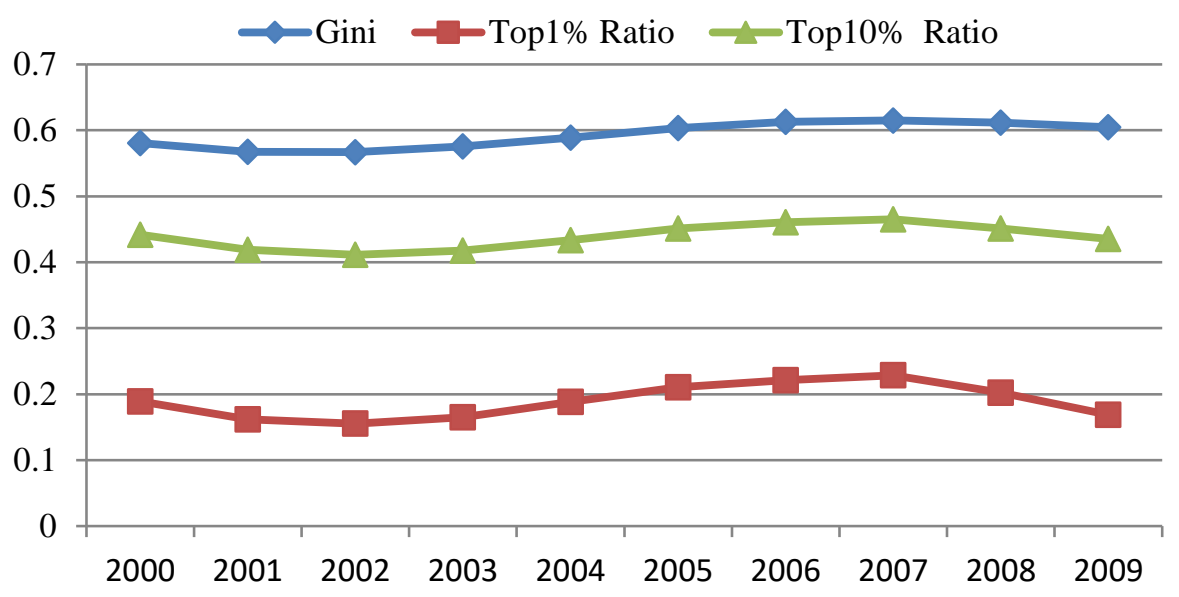

Note: The figure plots the annual mean of state values for the Gini coefficient, Top $1 \%$ and Top 10\% ratios. The ratios are the share of income captured by the top 1 percent and 10 percent of the income distribution, respectively (divided by 100).

Both EDI use and income inequality vary greatly by state and both have grown over the past several decades (Frank, 2009; Leight, 2010; Williams, 2014; Bartik, 2017). Numerous sources investigate the rising heterogeneity of intra-state inequality. From 1979 to 1999, for example, increases in state-level Gini coefficients ranged from 7 percent in Nebraska and Iowa to 22 percent in Connecticut (Hazanov and Izraeli, 2010). Florida (2014) also notes rising state-level Gini coefficients using GIS maps illustrating state-level trends from 1979 to 2012. ${ }^{9}$

The lopsided nature of income growth has also been recognized. The Economic Policy Institute (EPI) analysis by Sommeiller, Price, and Wazeter (2016), for instance, tracks trends in the top 1 percent income share (Top1\%) at the state, metropolitan, and county level in the U.S. from 1928 to 2013. ${ }^{10}$ Whereas equality increased from 1928 to 1979, this trend reversed from 1979 to 2007 where Top 1\% captured a larger share of income in every state. There are notable differences in within state inequality: some states, such as New York, Wyoming, Florida, and Nevada, have had bigger jumps in the Top $1 \%$ of income compared with the U.S. average. As we highlight below, the concentration of income in the top tiers declined from 2007 to 2009.

Inequality data are widely available. In the analysis that follows, we use Mark Frank's data constructed from individual tax filing data available from the Internal Revenue Service for all 50 states plus the District of Columbia. ${ }^{11}$ We focus on three common measures of inequality - the Gini coefficient, the Top $1 \%$, and the Top $10 \%$ share of income. The Top $1 \%$ and Top $10 \%$ measures capture concentration at the top of the distribution which may not be reflected in the Gini coefficient. Figure 1 plots the mean state values for all three measures from 2000 to 2009 where Top $1 \%$ and Top $10 \%$ are represented as ratios (percentage shares are divided by 100). Generally, all the measures move together and display cyclical behavior. Note how the rise and fall in the Top1\% share is more pronounced than the changes in the Gini coefficient. As expected, the co-

\footnotetext{
${ }^{9}$ The maps are available at the Martin Prosperity Institute website, http://martinprosperity.org/maps/inequality/index.html

${ }^{10}$ EPI has interactive visualization tools at http://www.epi.org/publication/income-inequality-in-the-us/.

${ }^{11}$ Mark Frank provides U.S. State-Level Income Inequality data which he updates regularly. The data used in this paper covers the years 1917 to 2012, downloaded from http://www.shsu.edu/eco_mwf/inequality.html.
}

(c) Southern Regional Science Association 2018. 
movements of the inequality measures vary by state. This suggests the need to consider state-level idiosyncrasies in the analysis of EDI-inequality links.

In contrast to inequality data, comprehensive data on EDI programs and expenditures are harder to obtain. For this paper, we use the Subsidy Tracker database constructed by Good Jobs First, a national, non-partisan organization. ${ }^{12}$ This database brings together public records of a wide variety of state and local EDI programs. Whereas the database includes twelve broad categories of tax and non-tax incentive programs, most of the spending is in just two categories: tax credits/rebates and grants/low-cost loans. This precludes estimation of impacts of individual categories in isolation. ${ }^{13}$

A key advantage of the data is that it tracks the dollar values of individual EDI expenditures by state and year. In contrast, Patrick's (2014a) Incentive Environment Index measure describes the legal environment where incentives can be used but does not capture the intensity of incentive use in terms of spending. Similarly, Goetz et al. (2011) use a measure of the share of potential programs that a state could use. Goetz et al. (2011) explain that this variable is "mildly positively" related with measures of economic development spending in previous studies. ${ }^{14}$ The Council for Community and Economic Research (C2ER) also tracks incentive spending in its State Economic Development Program Expenditures Database. This database omits tax expenditures which can be an important source of spending, leading to underestimates of EDI spending. ${ }^{15}$

The Subsidy Tracker data is likely to capture the biggest and most prominent EDI deals, which are most likely to impact redistribution of income to the wealthiest individuals. On the downside, the database is likely to exclude EDI that are smaller or in states which are less forthcoming with EDI deal details (Kenyon, Langley, and Paquin, 2012). Accordingly, the Subsidy Tracker database may not be useful for generalizing results to states which either do not report or do not use EDI very often. ${ }^{16}$ Another limitation is the aggregate reporting of multiple period EDI awards in a single year even though spending is likely to be spread out over many years. Thus, it is difficult to accurately assign actual yearly EDI expenditures. As we discuss below, using lagged values of EDI partially addresses this shortcoming.

Table 1 provides summary data for EDI programs included in the Subsidy Tracker database for our sample period, 2000 to 2009. In 2000, only 28 states had EDI values reported for at least one program included in the Subsidy Tracker database. The number of states with recorded EDI values increased throughout the period: by 2009, 45 states had EDI program values reported in the database. The total value of the EDI program values summed over all the states in the database also increased throughout the period, with a spike in 2007. Similarly, the mean value of total state EDI per year (e.g. column 4 of Table 1) gradually increased as well. As shown in columns five and six, the overall minimum and maximum values of EDI varied greatly throughout the period.

\footnotetext{
12 Subsidy Tracker database is available at http://www.goodjobsfirst.org/subsidy-tracker.

13 For a detailed description of incentives types included, please refer to the Subsidy Tracker user guide: http://www.goodjobsfirst.org/subsidy-tracker-user-guide. The twelve categories are: tax credits/rebates, property tax abatements, megadeal, grants/low-cost loans, enterprise zones, tax increment financing, training reimbursements, cost reimbursements, infrastructure assistance, industrial revenue bonds, tax credits/rebates and grants, and venture capital.

14 See Goetz et al. (2011) footnote 9.

${ }^{15}$ A scatter plot of the C2ER (vertical axis) and Subsidy Tracker data for 2007-2012, the years the databases overlap, shows that the majority of the points are below the 45 degree line.

${ }^{16}$ As discussed below, some states, including Alaska, Maine, Arkansas, and Rhode Island, only have EDI reported for a few years in the Subsidy Tracker database.
}

(C) Southern Regional Science Association 2018. 
Table 1: Summary of Subsidy Tracker EDI Data by Year

\begin{tabular}{|c|c|c|c|c|c|c|}
\hline $\begin{array}{c}\text { Sample } \\
\text { Year }\end{array}$ & $\begin{array}{c}\# \\
\text { States } \\
\end{array}$ & $\begin{array}{c}\text { Total EDI } \\
\text { Value } \\
\text { (thousand \$s) }\end{array}$ & $\begin{array}{c}\text { Mean EDI } \\
\text { Value } \\
\text { (thousand \$s) }\end{array}$ & $\begin{array}{c}\text { Min EDI } \\
\text { Value } \\
\text { (thousand \$s) }\end{array}$ & $\begin{array}{c}\text { Max EDI } \\
\text { Value } \\
\text { (thousand \$s) }\end{array}$ & $\begin{array}{c}\text { Standard } \\
\text { Deviation }\end{array}$ \\
\hline 2000 & 28 & $2,393,680$ & 85,489 & 249.36 & 725,900 & 158,117 \\
\hline 2001 & 25 & 706,428 & 28,257 & 217.39 & 144,774 & 41,783 \\
\hline 2002 & 31 & $1,857,954$ & 59,934 & 431.31 & 894,613 & 162,148 \\
\hline 2003 & 31 & 3,782,399 & 122,013 & 440.06 & $1,800,000$ & 332,155 \\
\hline 2004 & 30 & $2,816,521$ & 93,884 & 19.24 & $1,100,000$ & 204,383 \\
\hline 2005 & 33 & $2,504,264$ & 75,887 & 437.36 & 481,927 & 116,710 \\
\hline 2006 & 33 & $3,709,126$ & 112,398 & 254.49 & $1,200,000$ & 224,643 \\
\hline 2007 & 41 & $6,732,177$ & 164,199 & 141.07 & $3,400,000$ & 530,313 \\
\hline 2008 & 43 & $4,885,809$ & 113,623 & 388.73 & 585,458 & 157,676 \\
\hline 2009 & 45 & $6,736,642$ & 149,703 & 114.01 & $2,400,000$ & 371,438 \\
\hline Total & & $36,125,000$ & & & & \\
\hline
\end{tabular}

Table 2 shows the state level details of EDI included in the Subsidy Tracker database. Notably the level of reported EDI activity varies by state. The majority of the states (twenty-one) had EDI recorded for the entire ten-year period. Four states, Alaska, Arkansas, Maine, and Rhode Island, had two or fewer years of EDI recorded in the database. Another seven states had only three recorded years of EDI spending. Total yearly EDI spending ranged from $\$ 19,240$ (Louisiana in 2004) to $\$ 3.4$ billion (New York in 2007) and averaged \$106 million across all states and years in the database.

States exhibited a great amount of heterogeneity in reported EDI spending trends throughout the period. This could be due to underreporting. Some states like Iowa (see Figure 2a) had a cyclical pattern of recorded EDI. Others like Kentucky (see Figure 2b) had steady use with a few peak years. And still others like New Jersey (See Figure 2c) had big jumps in EDI spending from year to year as reported in Subsidy Tracker. The recorded data suggests that New Jersey's

Table 2: Summary of Subsidy Tracker Recorded EDI Values $\mathbf{( \$ 1 , 0 0 0 s )}$ by Year

\begin{tabular}{lcccc}
\hline \hline & Frequency & Average & Minimum & Maximum \\
\hline Alaska* & 1 & 114 & 114 & 114 \\
Arkansas* & 1 & 629 & 629 & 629 \\
Maine* & 2 & 18,506 & 3,164 & 33,848 \\
Rhode Island* & 2 & 19,970 & 16,375 & 23,566 \\
Nebraska & 3 & 1,373 & 763 & 2,023 \\
New Hampshire & 3 & 305 & 141 & 548 \\
Oklahoma & 3 & 108,472 & 101,452 & 112,812 \\
South Carolina* & 3 & 187,271 & 57,532 & 419,580
\end{tabular}

(c) Southern Regional Science Association 2018. 
Table 2 Continued

\begin{tabular}{|c|c|c|c|c|}
\hline & Frequency & Average & Minimum & Maximum \\
\hline South Dakota & 3 & 4,787 & 2,124 & 7,886 \\
\hline Utah & 3 & 52,363 & 33,783 & 79,986 \\
\hline West Virginia & 3 & 23,940 & 1,243 & 69,294 \\
\hline Mississippi* & 4 & 243,432 & 25,986 & 725,900 \\
\hline Montana & 4 & 2,073 & 563 & 3,278 \\
\hline Pennsylvania & 4 & 11,120 & 2,658 & 23,057 \\
\hline Alabama & 5 & 164,967 & 3,549 & 518,526 \\
\hline Kansas & 5 & 33,611 & 2,082 & 78,478 \\
\hline Tennessee & 5 & 194,678 & 74,515 & 498,356 \\
\hline Washington & 7 & 319,908 & 20,355 & $1,800,000$ \\
\hline Arizona & 8 & 13,149 & 4,186 & 54,650 \\
\hline California & 8 & 43,372 & 15,075 & 177,316 \\
\hline Oregon & 8 & 78,610 & 1,612 & 481,927 \\
\hline Idaho & 9 & 15,576 & 409 & 128,465 \\
\hline Indiana & 9 & 189,271 & 40,313 & 402,223 \\
\hline Michigan & 9 & 381,473 & 4,546 & $2,400,000$ \\
\hline Nevada & 9 & 6,232 & 1,743 & 16,159 \\
\hline New Mexico & 9 & 176,007 & 1,401 & $1,100,000$ \\
\hline Colorado & 10 & 1,505 & 342 & 7,741 \\
\hline Connecticut & 10 & 63,063 & 2,973 & 212,590 \\
\hline Delaware & 10 & 1,569 & 249 & 11,834 \\
\hline Florida & 10 & 128,188 & 22,835 & 332,995 \\
\hline Georgia & 10 & 36,283 & 279 & 208,500 \\
\hline Illinois & 10 & 101,424 & 27,311 & 189,339 \\
\hline Iowa & 10 & 72,331 & 4,655 & 164,362 \\
\hline Kentucky & 10 & 193,739 & 75,127 & 546,560 \\
\hline Louisiana & 10 & 87,773 & 19 & 525,685 \\
\hline Maryland & 10 & 9,556 & 1,307 & 19,839 \\
\hline Minnesota & 10 & 24,799 & 8,735 & 46,917 \\
\hline Missouri & 10 & 102,222 & 22,735 & 388,677 \\
\hline New Jersey & 10 & 91,498 & 16,607 & 181,885 \\
\hline New York & 10 & 821,940 & 40,042 & $3,400,000$ \\
\hline North Carolina & 10 & 118,355 & 596 & 332,230 \\
\hline North Dakota & 10 & 2,581 & 1,498 & 3,766 \\
\hline Ohio & 10 & 103,476 & 2,931 & 347,798 \\
\hline Texas & 10 & 169,705 & 337 & 445,772 \\
\hline Vermont & 10 & 6,288 & 2,604 & 11,747 \\
\hline Virginia & 10 & 7,724 & 217 & 25,237 \\
\hline Wisconsin & 10 & 24,137 & 3,490 & 82,966 \\
\hline
\end{tabular}

Note: States excluded from sample due to data limitations are Hawaii, Massachusetts and Wyoming, which have no EDI recorded during the sample period in Subsidy Tracker database. EDI values are deflated by CPI (1982-1984).

(C) Southern Regional Science Association 2018. 
Figure 2a: Iowa has Pro-cyclical EDI

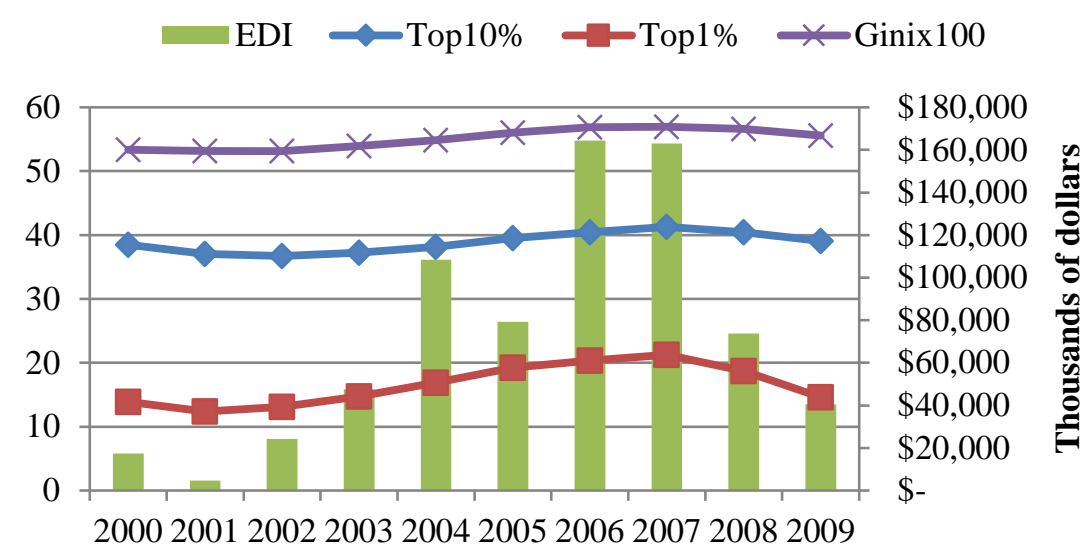

Figure 2b: Kentucky has a few high EDI years

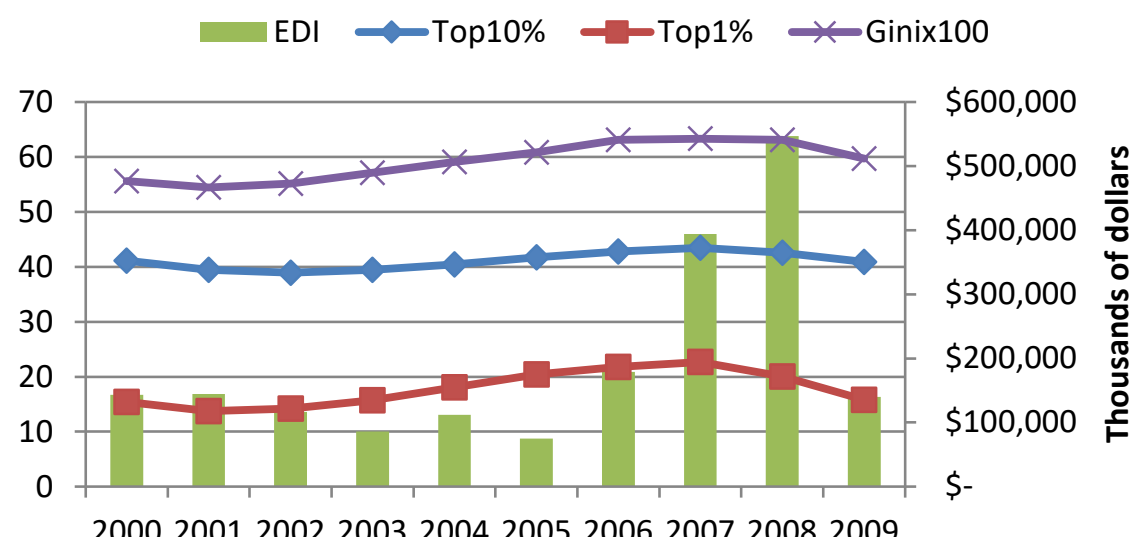

Figure 2c: New Jersey has EDI spikes

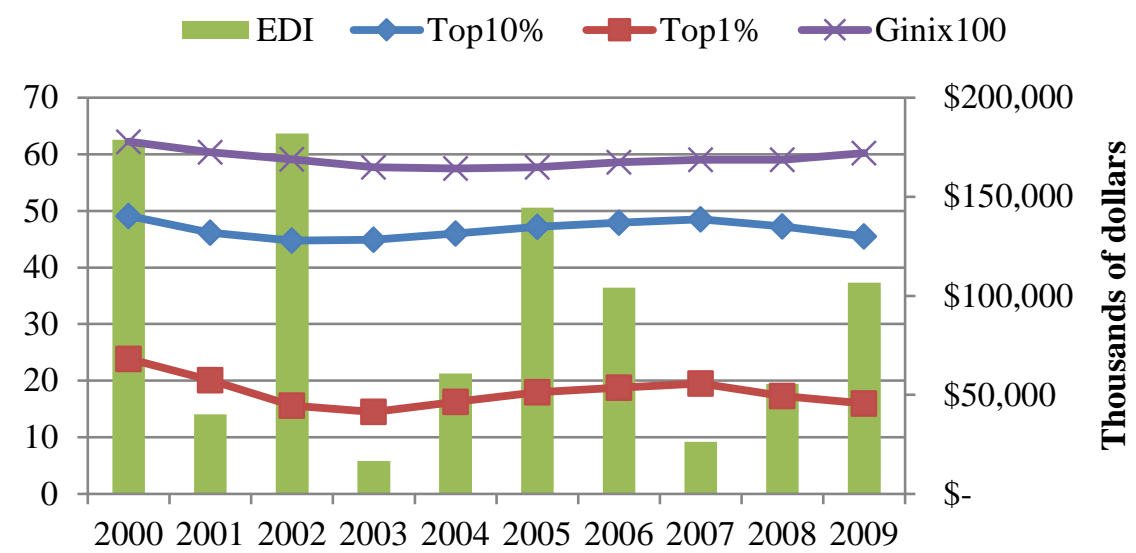

Note: each point represents the average state EDI spending and Gini coefficient $(n=47)$ over the 2000-2009 period.

(C) Southern Regional Science Association 2018. 
Figure 3: State Gini Coefficient \& EDI Spending averages

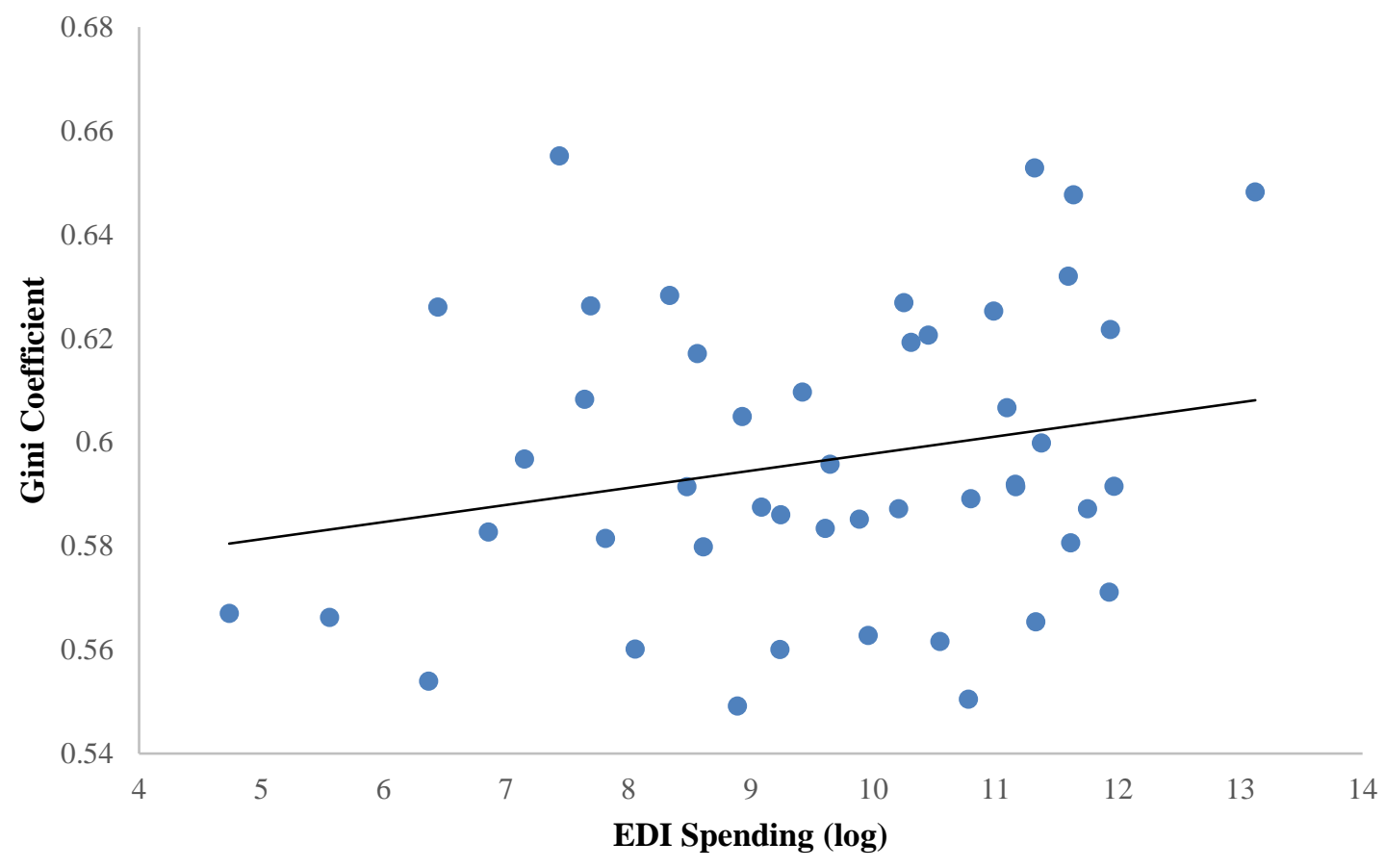

Note: 47 states are included. Each point represents average state EDI spending and Gini coefficient over the 2000-2009 period.

spikes are driven by unusually large grants and Megadeals. ${ }^{17}$ Since all states are unique, it is difficult to glean overall patterns by looking at states individually.

Figure 3 plots the yearly averages of state total EDI spending and Gini coefficients over the 2000 to 2009 period. Casual observation suggests that the use of EDI is correlated with statelevel inequality. The point at the upper right corner is New York, a state that uses EDI prolifically. At the other extreme in the lower left, is Alaska, which only has reported EDI values for 2009 in the database. Visual inspection suggests a positive linear relationship between state average EDI use and the average Gini coefficient over the 2000 to 2009 period. The graphs plotting EDI against Top $1 \%$ and Top $10 \%$ look very similar. ${ }^{18}$

\section{PANEL ESTIMATION STRATEGY}

Our goal is to investigate the EDI-inequality link controlling for other important factors which might influence inequality. Following Goetz et al. (2011), we employ a state-level approach to capture the great variability in EDI programs and spending across states, and use lagged values of EDI to account for potential endogeneity. Following Shaui (2015) we use direct measures of economic development program activities.

\footnotetext{
17 The spikes in New Jersey’s EDI spending are explained as follows: in 2000 there was a grant of over \$300 million, twice the average value; in 2002 there was a \$290 million Megadeal; in 2005 and 2009 combined spending on grants, Megadeals and tax credits/rebates was high; and in 2006 grants and tax credits/rebates were high. However, if tax credits/rebates were used in huge amounts (more than \$200 million) before 2005 but not reported, then the spikes in year 2000 and 2002 could be due to underreporting.

${ }^{18}$ The relationships are also similar for the sample observations used in the analysis that follows. This gives some confidence that our sample is representative of the fuller data set.
}

(C) Southern Regional Science Association 2018. 
The relationship between EDI spending and inequality measures is estimated using the following panel model:

$$
y_{i t}=\beta E D I_{i t-1}+\boldsymbol{x}_{i t} \boldsymbol{\gamma}+\delta_{i}+\alpha t+\varepsilon_{i t},
$$

where the dependent variable $y_{i t}$ is one of the three inequality measures (Top $1 \%$, Top $10 \%$, or the Gini coefficient) for state $i$ in year $t$. Following Goetz et al (2011), we use the one year lag of EDI spending to alleviate concerns about policy endogeneity. ${ }^{19}$ Lagged EDI spending is expressed as a percentage of total direct expenditures at the state level. $\boldsymbol{x}_{i t}$ is a vector of conditioning variables (including an intercept) that are thought to influence inequality. State fixed effects $\left(\delta_{i}\right)$ account for time-invariant state specific characteristics. Parameter $\alpha$ is associated with the time trend, which controls for the general movement in inequality measures over time. $\beta$ is our parameter of interest here. The estimation uses robust standard errors clustered to the state level.

The explanatory variables capture economic, demographic, and political factors. Economic variables include per capita income and its square to account for possible non-linear impacts, top statutory state corporate income tax rate, top statutory personal income tax rate, jobless rate, manufacturing share of employment, and welfare spending at the state level. The spending variables are on a per capita basis and deflated using CPI with 1982-1984 as the base year. Demographic characteristics include proportions of the elderly population (age $>65$ ) and young population $(\mathrm{age}<15) .{ }^{20}$ Additional socioeconomic variables include years of education, union membership, corruption, and democratic control at the state level. Union membership is measured as the percentage of nonagricultural employees covered by a collective bargaining agreement (Hirsh and McPherson, 2003). ${ }^{21}$ Corruption is calculated as the number of federal public corruption convictions per one million residents based on reports from U.S. Department of Justice (Felix and Hines, 2013). Democratic control is set to equal 1 if both the state governor and legislature belong to the Democratic Party and is 0 otherwise. ${ }^{22}$ This variable is included to investigate whether bipartisanship impacts inequality measures.

Data availability restricts the sample to 41 states over the period 2000-2009 for a total of 279 observations. ${ }^{23}$ Given that the model has lagged values of EDI, EDI observations that did not occur in back to back years in a state are dropped from the sample. Mississippi and South Carolina were dropped from the sample because few years of EDI data were recorded in consecutive years. ${ }^{24}$ It is possible that some EDI were not recorded in the data which raises concerns about

\footnotetext{
${ }^{19}$ To explore potential endogeneity, we performed an endogeneity test on Lag EDI using the 2 year lag of EDI as the instrument. The results indicated that lagged EDI is not endogenous - we fail to reject the null that the regressor is exogenous. Further, when we estimated the model using the two year lag instead of the one year lag of EDI, the estimated coefficients are not statistically significant.

${ }^{20}$ Government finance data, employment, and demographic characteristics are obtained from the U.S. Census. Personal income and unemployment rates are from the Bureau of Economic Analysis (BEA). Top statutory state corporate income tax rate and top statutory state personal income tax rate data are collected from Tax Foundation and Tax Policy Center respectively.

${ }^{21}$ Hirsh and Macpherson provide annual updates of union membership information posted at http://www.unionstats.com/.

${ }^{22}$ The political affiliation information is provided by the National Governor Association (NGA) and National Conference of State Legislatures (NCSL)

${ }^{23}$ To test for robustness, we also estimated the baseline model using a balanced panel with 28 states from the original sample for the period 2002-2008. See Section 6.3 for discussion.

${ }^{24}$ These states were unlikely to have had large, unobserved EDI during the period, but deals of smaller values may not have been observed. Rather than impute value for the "missing years" we omitted these states.
}

(C) Southern Regional Science Association 2018. 
Table 3: Summary Statistics $(\mathbf{n}=279)$

\begin{tabular}{ccccc}
\hline \hline & & Std. & & \\
Variables & Mean & Dev. & Min & Max \\
\hline Gini & 0.59 & 0.04 & 0.53 & 0.69 \\
Top1\% & 0.19 & 0.03 & 0.12 & 0.28 \\
Top10 & 0.44 & 0.04 & 0.37 & 0.57 \\
EDI(lag) & 0.37 & 1.05 & 0.0001 & 14.25 \\
Welfare Expenditures & 0.58 & 0.16 & 0.27 & 1.14 \\
Personal Income PC & 18.00 & 2.48 & 13.93 & 26.95 \\
Income squared & 330.07 & 95.87 & 194.17 & 726.08 \\
Education & 13.67 & 0.35 & 12.19 & 14.45 \\
Jobless Rate & 5.42 & 1.71 & 2.8 & 13.3 \\
\% Union & 11.73 & 5.48 & 2.8 & 26.9 \\
\%Pop_above65 & 12.65 & 1.55 & 8.83 & 17.32 \\
\%Pop_below15 & 20.35 & 1.37 & 16.80 & 26.79 \\
Corruption & 3.45 & 2.77 & 0 & 25.05 \\
Democratic Control & 0.23 & 0.42 & 0 & 1 \\
Corporate Tax Rate & 0.06 & 0.04 & 0 & 0.12 \\
Individual Tax Rate & 0.05 & 0.03 & 0 & 0.12 \\
\%Manufacturing Emp & 11.70 & 4.33 & 4.01 & 22.64 \\
\hline \hline
\end{tabular}

Notes: Gini coefficient, Top1\% and Top10\% shares of income are inequality outcome measures. Lagged EDI is expressed as a percentage of total expenditures at the state level. Personal Income per capita is in $\$ 1000$ s. Along with welfare expenditures per capital, they are deflated to 1982-1984 CPI. Education is in years. Jobless rate is \% of unemployed. Union membership is \% of nonagricultural employees covered by collective bargaining. Corruption is public corruption convictions per million residents. Democratic control occurs when the governor and legislature are held by Democratic Party. Tax rates are the top statutory rates imposed. \%Manufacturing Employment is share of employment in manufacturing.

omitted variable bias. Very large EDI deals are likely be noticed. ${ }^{25}$ In contrast, unobserved EDI are likely to be small in value, and thus, less likely to impact state-level inequality. Further, there is no reason, a priori, to expect that unrecorded EDI would systematically impact the relationship between inequality and EDI spending. Finally, we note that the scatter plot of EDI spending and the Gini coefficient for the sample looks very similar to the one for the complete data shown in Figure 3.

Summary statistics for the sample are given in Table 3. EDI spending as a percentage of direct total expenditures varied widely: ranging from less than 0.0001 percent (Michigan in 2006) to 14.25 percent (Ohio in 2002) with an average of 0.37 percent across all states and years. The Top1\% income share is highest in New York in 2001 (0.28) and lowest in Iowa in 2001 (0.12) with an average of 0.19 . The Top $1 \%$ income share is highest in Oregon in 2005 (0.57) and lowest in Kentucky in 2003 (0.37) with an average of 0.44. The Gini coefficient is highest in Florida in 2007 (0.69) and lowest in Ohio in 2001 (0.53) with an overall average of 0.59. Most of the explanatory variables display wide ranges in values across states. For example, the manufacturing share of employment ranges from 4.01 percent to 22.64 percent, the corruption rate ranges from

\footnotetext{
25 There is a case for estimating models with just the Megadeals, given the unlikely chances of any being omitted from the sample. However, given that Megadeals are rarer, the resulting sample size would be reduced and the results would not generalize to EDI policy across all states and all types of deals.
} 
zero to a high of 25.05 in North Dakota in 2003, and union membership is highest in New York in 2001 (26.9 percent) and lowest in North Carolina in 2004 (2.8 percent). Per capita expenditures on public welfare programs are comparatively small among the public expenditure categories, ranging from a high of \$1.14 per capita in New York in 2005 to a low of \$0.27 per capita in Nevada in 2001.

\section{RESULTS}

\subsection{Baseline Results}

Table 4 displays results for the baseline estimation, the panel model with state fixed effects corresponding to Equation (1), estimated using robust standard errors clustered by state. The estimates for the three inequality outcome measures are presented in separate columns. Standard errors are in parentheses and stars by coefficient estimates denote the usual levels of significance. ${ }^{26}$

Looking at the baseline estimates in Table 4, the coefficient estimates on lagged EDI spending are positive and significant at the one percent level of significance for the Gini and Top $1 \%$ models, and at five percent level of significance for the Top $10 \%$ model. This indicates that higher EDI spending in the previous year is associated with increased income inequality and increased income concentration for the wealthiest income groups. More specifically, a one percentage point increase in EDI spending (as a percentage of total direct expenditure) is associated with a 0.002 increase in both the Gini coefficient and the Top $1 \%$ share, and a 0.001 increase in Top $10 \%$ share a year later. At the mean values, a 10 percentage point increase in EDI would be predicted to increase the Gini from 0.59 to 0.61 , the Top $1 \%$ share from 0.19 to 0.21 and the Top $10 \%$ share from 0.44 to 0.45 . It is notable that the impact is biggest in absolute size for the wealthiest income group. Whereas these impacts are small, they are immediate short run impacts: full impacts are likely to take a longer period of time, especially given that EDI are allocated over several years but recorded only in the initial year in the Subsidy Tracker Database.

It is interesting to contrast the estimated impacts of EDI with spending on income redistribution programs captured by welfare expenditures. The negative sign and statistical significance on the estimated coefficient on welfare expenditures suggests that increased spending on these programs is linked with more equal distribution of income. The estimates suggest that a one dollar per capita increase in the welfare expenditures would decrease the Gini coefficient by 0.098. The negative relationship is strongest for the Top $1 \%$ group, which would be predicted to drop by almost half at the mean (from 0.19 to 0.116 ) as a result of a one dollar per capita increase in welfare expenditures. Taken together, if policymakers were interested in offsetting the income redistribution attributable to a one percent point increase in EDI spending (as a percentage of total direct expenditure), then welfare expenditures would need to be increased by about $\$ 0.22$ per capita on average.

The estimated coefficients for demographic variables are as expected. Having a more educated population is associated with higher degree of income equality, although only the coefficient for the Top1\% is statistically significant. Having a more elderly and younger population is also associated with more equality, likely due to the low wages or lack of employment for individuals in these groups. The estimated income coefficient is positive and the income squared

$26 * * *$ for $\mathrm{p}<0.01$, ** for $\mathrm{p}<0.05$ and $*$ for $\mathrm{p}<0.1$.

(C) Southern Regional Science Association 2018. 
Table 4: Baseline Panel Regression

\begin{tabular}{|c|c|c|c|}
\hline & Gini & Top1\% & Top10\% \\
\hline \multirow[t]{2}{*}{ EDI (lag) } & 0.002 & 0.002 & 0.001 \\
\hline & $(0.000)^{* * *}$ & $(0.001)^{* * *}$ & $(0.000)^{* *}$ \\
\hline \multirow[t]{2}{*}{ Welfare Expenditure } & -0.098 & -0.074 & -0.027 \\
\hline & $(0.021)^{* * *}$ & $(0.028) * *$ & $(0.014)^{*}$ \\
\hline \multirow[t]{2}{*}{ Education } & -0.001 & -0.028 & -0.006 \\
\hline & $(0.009)$ & $(0.011)^{* *}$ & $(0.006)$ \\
\hline \multirow[t]{2}{*}{ \%Pop_above65 } & -0.005 & -0.020 & -0.018 \\
\hline & $(0.009)$ & $(0.01)^{*}$ & $(0.004)^{* * *}$ \\
\hline \multirow[t]{2}{*}{ \%Pop_below15 } & -0.017 & -0.030 & -0.012 \\
\hline & $(0.007) * *$ & $(0.008) * * *$ & $(0.004)^{* * *}$ \\
\hline \multirow[t]{2}{*}{ Personal Income PC } & 0.038 & 0.027 & 0.013 \\
\hline & $(0.016)^{* *}$ & $(0.011)^{* *}$ & $(0.01)$ \\
\hline \multirow[t]{2}{*}{ Person Income squared } & -0.001 & -0.001 & 0.000 \\
\hline & $(0.000)^{* *}$ & $(0.000)^{* * *}$ & $(0.000)$ \\
\hline \multirow[t]{2}{*}{ \%Manufacturing Emp } & -0.002 & -0.002 & -0.004 \\
\hline & $(0.002)$ & $(0.003)$ & $(0.001)^{* * *}$ \\
\hline \multirow[t]{2}{*}{ \%Union } & -0.001 & -0.002 & -0.002 \\
\hline & $(0.001)$ & $(0.001)^{*}$ & $(0.001)^{* *}$ \\
\hline \multirow[t]{2}{*}{ Jobless Rate } & -0.005 & -0.015 & -0.008 \\
\hline & $(0.001)^{* * *}$ & $(0.001)^{* * *}$ & $(0.001)^{* * *}$ \\
\hline \multirow[t]{2}{*}{ Corruption } & 0.000 & 0.000 & 0.000 \\
\hline & $(0.000)$ & $(0.000)$ & $(0.000)$ \\
\hline \multirow[t]{2}{*}{ Democratic Control } & -0.002 & -0.007 & -0.006 \\
\hline & $(0.006)$ & $(0.004)^{*}$ & $(0.002)^{* * *}$ \\
\hline \multirow[t]{2}{*}{ Corp Income Tax Rate } & 0.045 & 0.103 & 0.064 \\
\hline & $(0.027)^{*}$ & $(0.034) * * *$ & $(0.028) * *$ \\
\hline \multirow[t]{2}{*}{ Indiv Income Tax Rate } & 0.079 & 0.044 & -0.009 \\
\hline & $(0.061)$ & $(0.07)$ & $(0.05)$ \\
\hline \multirow[t]{2}{*}{ Year } & 0.007 & 0.008 & 0.006 \\
\hline & $(0.002)^{* * *}$ & $(0.001)^{* * *}$ & $(0.001)^{* * *}$ \\
\hline
\end{tabular}

Notes: Panel regressions are estimated for each inequality measure, Gini, Top1\% and Top $10 \%$ shares of income for 41 states from 2000 to 2009. Reported standard errors are clustered by state and are reported in parentheses. The explanatory variable EDI(lag) is the one-year lag of state EDI spending expressed as a percentage of state total direct expenditures. See Table 3 for description of other control variables. Levels of significance are indicated by convention: $* * *$ for $\mathrm{p}<0.01, * *$ for $\mathrm{p}<0.05$ and $*$ for $\mathrm{p}<0.1$

coefficient is negative, which is consistent with Kuznets' hypothesis predicting that income inequality first worsens and then improves over the course of economic development. ${ }^{27}$

Consistent with the literature on channels impacting inequality, greater shares of manufacturing employment and union membership are associated with less income inequality. The estimated coefficients on the jobless rate are negative and significant at the one percent level for

\footnotetext{
${ }^{27}$ Kim, Huang, and Lin (2011) estimate the opposite pattern using data for U.S. states from 1945-2004. We note that our period is too short to capture long run effects.
}

(c) Southern Regional Science Association 2018. 
all three income inequality measures. This is counter to the common perception that unemployment increases income inequality. However, it is likely that the counterintuitive result reflects the sample period: between 2000 and 2009, manufacturing employment in the U.S. fell from 17.3 million to 11.7 million (Scott, 2015). ${ }^{28}$ Political factors are also noteworthy. Democratic control is found to be associated with less inequality and the impact is statistically significant for the Top $1 \%$ and Top $10 \%$ measures. Tax policy may also influence income distribution. Our results find a positive and statistically significant relationship between the top statutory corporate income tax rate and all three income inequality measures. Whereas this seems counterintuitive, tax schemes are complex: the top statutory rate is unlikely to capture nuances or to reflect effective tax rates. $^{29}$

Finally, the estimated coefficients for the time trend are positive and significant at the one percent level in all three regressions, consistent with recent research documenting rising inequality (Hazanov and Izraeli, 2010; Williams, 2014; Florida, 2014; Diamond, 2016).

\subsection{Exploring Regional Effects}

Regional factors are often important in policy innovation and diffusion. The use of EDI could be more intense in some regions, thus driving up EDI values without impacting potential growth outcomes. On the other hand, states have recently improved evaluation of incentives, much to the credit of the influence of the Pew Charitable Trust (2017). Regional trends in accountability could lead to EDI strategies that are more effective in promoting growth and less likely to increase inequality. ${ }^{30}$

To investigate potential regional influences, we add regional dummy variables and EDIregional dummy interaction terms to the basic regression equation. Specifically, we include a dummy variable for each Census division: New England, Mid Atlantic, South Atlantic, East North Central, East South Central, West North Central, West South Central, and Mountain where the Pacific Division is omitted to avoid multicollinearity problems. ${ }^{31}$

Table 5 provides the estimation using the Census division effects. Estimates for the coefficients on control variables are qualitatively similar to baseline estimates. The estimated impacts of some control variables become less significant. Lagged EDI spending itself is positively associated with Top $1 \%$ and Top $10 \%$, but its estimated coefficient is no longer statistically significant under the Gini coefficient model.

For the Gini coefficient model shown in Column (1), EDI use in the previous year is associated with more unequal income distribution for states in New England, East North Central, and West South Central (relative to the Pacific Division). Focusing on estimates on interaction terms in Column (2), being in the Middle Atlantic, East South Central, West South Central, and Mountain Divisions is associated with additional decreases in Top1\%, whereas being in the South Atlantic and West North Central has the opposite effect. The magnitudes of coefficient on lagged

\footnotetext{
${ }^{28}$ Source of data is “EPI analysis of Bureau of Labor Statistics (2015a).” Available at: http://www.epi.org/publication/manufacturing-job-loss-trade-not-productivity-is-the-culprit/

29 This finding warrants further investigation. We note that the top statutory rate may not be indicative of effective tax rate considering tax base definitions. It is also possible, but not likely given political economy factors, that states increase income tax rates in response to growing income at the top income groups.

${ }^{30}$ See Pew 2017 page 2 for a chart suggesting regional patterns in EDI evaluation.

${ }^{31}$ Note that individual state fixed effects are dropped in this case due to collinearity. The dummy for the Pacific division is omitted.

(C) Southern Regional Science Association 2018.
} 
Table 5: Panel Regression with Regional Dummy Variables

\begin{tabular}{|c|c|c|c|}
\hline & Gini & Top 1\% & Top $10 \%$ \\
\hline \multirow[t]{2}{*}{ EDI (lag) } & 0.001 & 0.003 & 0.002 \\
\hline & $(0.001)$ & $(0.001)^{* * *}$ & $(0.000)^{* * *}$ \\
\hline \multirow[t]{2}{*}{ Welfare Exp } & -0.074 & -0.029 & -0.020 \\
\hline & $(0.021) * * *$ & $(0.023)$ & $(0.015)$ \\
\hline \multirow[t]{2}{*}{ Education } & -0.003 & -0.025 & -0.009 \\
\hline & $(0.008)$ & $(0.011)^{* *}$ & $(0.006)$ \\
\hline \multirow[t]{2}{*}{ \%Pop_above 65} & -0.001 & -0.005 & -0.009 \\
\hline & $(0.005)$ & $(0.006)$ & $(0.003)^{* * *}$ \\
\hline \multirow[t]{2}{*}{ \%Pop_below 15} & -0.006 & -0.005 & -0.006 \\
\hline & $(0.005)$ & $(0.005)$ & $(0.004)$ \\
\hline \multirow[t]{2}{*}{ Personal Income PC } & 0.038 & 0.026 & 0.012 \\
\hline & $(0.015)^{* *}$ & $(0.008)^{* * *}$ & $(0.009)$ \\
\hline \multirow[t]{2}{*}{ Pers. Income squared } & -0.001 & -0.001 & 0.000 \\
\hline & $(0.000)^{* * *}$ & $(0.000)^{* * *}$ & $(0.000)$ \\
\hline \multirow[t]{2}{*}{ \%Manufacturing Emp } & -0.003 & -0.003 & -0.005 \\
\hline & $(0.001)^{* * *}$ & $(0.002)^{*}$ & $(0.001)^{* * *}$ \\
\hline \multirow[t]{2}{*}{ \%Union } & -0.001 & -0.001 & -0.001 \\
\hline & $(0.001)$ & $(0.001)$ & $(0.001)^{* *}$ \\
\hline \multirow[t]{2}{*}{ Jobless rate } & -0.004 & -0.013 & -0.008 \\
\hline & $(0.001)^{* * *}$ & $(0.001)^{* * *}$ & $(0.001)^{* * *}$ \\
\hline \multirow[t]{2}{*}{ Corruption } & 0.000 & 0.000 & 0.000 \\
\hline & $(0.000)$ & $(0.001)$ & $(0.000)$ \\
\hline \multirow[t]{2}{*}{ Democratic Control } & -0.004 & -0.012 & -0.007 \\
\hline & $(0.006)$ & $(0.004)^{* * *}$ & $(0.003)^{* * *}$ \\
\hline \multirow[t]{2}{*}{ Corporate tax rate } & 0.044 & 0.088 & 0.053 \\
\hline & $(0.031)$ & $(0.04)^{* *}$ & $(0.031)^{*}$ \\
\hline \multirow[t]{2}{*}{ Individual tax rate } & 0.108 & 0.020 & -0.027 \\
\hline & $(0.07)$ & $(0.076)$ & $(0.05)$ \\
\hline \multirow[t]{2}{*}{ Year } & 0.007 & 0.008 & 0.005 \\
\hline & $(0.001)^{* * *}$ & $(0.001)^{* * *}$ & $(0.001)^{* * *}$ \\
\hline \multirow[t]{2}{*}{ New England Division } & 0.017 & -0.004 & -0.005 \\
\hline & $(0.034)$ & $(0.021)$ & $(0.033)$ \\
\hline \multirow[t]{2}{*}{ Middle Atlantic Division } & 0.045 & 0.012 & 0.027 \\
\hline & $(0.031)$ & $(0.025)$ & $(0.027)$ \\
\hline \multirow[t]{2}{*}{ South Atlantic Division } & -0.026 & -0.036 & -0.035 \\
\hline & $(0.021)$ & $(0.014)^{* *}$ & $(0.02)^{*}$ \\
\hline \multirow[t]{2}{*}{ East North Central Div } & 0.008 & 0.014 & 0.006 \\
\hline & $(0.019)$ & $(0.013)$ & $(0.015)$ \\
\hline \multirow[t]{2}{*}{ West South Central Div } & 0.021 & -0.013 & -0.015 \\
\hline & $(0.021)$ & $(0.013)$ & $(0.016)$ \\
\hline \multirow[t]{2}{*}{ Mountain Division } & -0.003 & -0.018 & -0.033 \\
\hline & $(0.021)$ & $(0.016)$ & $(0.017) * *$ \\
\hline
\end{tabular}

(c) Southern Regional Science Association 2018. 
Table 5 Continued

\begin{tabular}{cccc}
\hline \hline NExEDI & 0.015 & 0.003 & -0.003 \\
& $(0.006)^{* *}$ & $(0.006)$ & $(0.004)$ \\
MAxEDI & 0.002 & -0.006 & -0.002 \\
& $(0.004)$ & $(0.003)^{*}$ & $(0.003)$ \\
SAxEDI & 0.009 & 0.014 & 0.005 \\
ENCxEDI & $(0.007)$ & $(0.006)^{* *}$ & $(0.005)$ \\
& 0.007 & 0.002 & 0.005 \\
ESCxEDI & $(0.003)^{* *}$ & $(0.004)$ & $(0.004)$ \\
& -0.004 & -0.006 & -0.003 \\
WNCxEDI & $(0.003)$ & $(0.002)^{* *}$ & $(0.003)$ \\
& 0.001 & 0.022 & 0.005 \\
WSCxEDI & $(0.005)$ & $(0.004)^{* * *}$ & $(0.002)^{* *}$ \\
& -0.011 & -0.025 & -0.002 \\
MTxEDI & $(0.005)^{* *}$ & $(0.005)^{* * *}$ & $(0.003)$ \\
& 0.001 & -0.001 & -0.001 \\
Panel regressions use same data and control variables as the baseline panel results in Table 4. Standard errors are \\
clustered by state and reported in parentheses. The dummy variable for the Pacific region is omitted. The \\
explanatory variable of interest, EDI(lag), is the one-year lag of state EDI spending. Levels of significance are \\
indicated by convention: *** for p<0.01, ** for p<0.05 and * for p<0.1
\end{tabular}

EDI along with the interaction terms suggest that Top1\% share is negatively associated with lagged EDI use in three divisions (relative to Pacific Division), while the net effect of lagged EDI use on Top 10\% is positive for all divisions with West North Central and Mountain having larger positive impacts (relative to Pacific). Taken together, these results suggest that EDI impacts on state inequality are likely to vary by region.

\subsection{Robustness Tests}

The difficulty in observing EDI values over states raises concern about nonrandom sampling and missing data. In our baseline estimates we used an unbalanced panel, dropping observations for which consecutive years were not recorded. To test for robustness, we estimated the baseline model using a balanced panel for the period 2002-2008. The balanced panel approach resulted in a sample with only 28 of the original 41 states and a smaller overall sample size (168 vs. 279). As shown in Table 6, the results were qualitatively similar for the key factors: lagged EDI is still positively correlated with all inequality measures and the relationship is statistically significant at the 1 percent level. The coefficient estimates on Gini and Top $1 \%$ decrease in magnitude whereas the coefficient estimate for Top $10 \%$ increases in magnitude.

We also estimated the benchmark specification using C2ER State Economic Development Program Expenditures data for all states for the 2007 to 2012 period. ${ }^{32}$ These data include comparable out-of-pocket EDI spending across states over time but lack information on any local EDI or EDI in the form of forgone tax revenues. Due to differences in treatment of out-of-pocket expenses, coverage of states and time periods, the estimates are not directly comparable to the baseline estimates. As shown in Table 6, the coefficient estimates for lagged EDI are all positive.

32 Two observations are missing which explains the sample size being 248 instead of 250. 
Table 6: Summary of Robustness Tests

\begin{tabular}{|c|c|c|c|}
\hline & $\begin{array}{c}\text { Baseline Panel } \\
\text { EDI (lag) }\end{array}$ & $\begin{array}{c}\text { Balanced Panel } \\
\text { EDI (lag) }\end{array}$ & $\begin{array}{c}\text { C2ER Sample } \\
\text { EDI (lag) }\end{array}$ \\
\hline \multicolumn{4}{|l|}{ Inequality } \\
\hline \multicolumn{4}{|l|}{ Measure } \\
\hline \multirow[t]{2}{*}{ Gini } & 0.002 & 0.0012 & 0.0008 \\
\hline & $(0.0000) * * *$ & $(0.0000) * * *$ & $(0.0057)$ \\
\hline \multirow[t]{2}{*}{ Top 1\% } & 0.002 & 0.0008 & 0.0002 \\
\hline & $(0.0010) * * *$ & $(0.0000)^{* *}$ & $(0.0060)$ \\
\hline \multirow[t]{2}{*}{ Top 10\% } & 0.001 & 0.056 & 0.0045 \\
\hline & $(0.0000)^{* * *}$ & $(0.0013) * * *$ & $(0.0026)^{*}$ \\
\hline \multicolumn{4}{|l|}{$\begin{array}{l}\text { Sample } \\
\text { description }\end{array}$} \\
\hline Sample Years & 2000-2009 & $2002-2008$ & 2007-2012 \\
\hline \# of states & 41 states & 28 states & 50 states \\
\hline Obs & 279 & 168 & 248 \\
\hline \multicolumn{4}{|c|}{$\begin{array}{l}\text { Notes: Regressions are clustered at the state level. One-year lag of EDI spending is the explanatory variable of } \\
\text { interest. Control variables are the same as in Table } 4 \text {. Baseline results are from Table } 4 \text {. The balanced panel estimates } \\
\text { include states for which no observations years were dropped. The baseline and balanced panel regressions use the } \\
\text { Subsidy Tracker data. C2ER regression uses the Council for Community and Economic Research State Business } \\
\text { Incentives data. Standard errors are reported in parentheses. Levels of significance are indicated by convention: }{ }^{* * *} \\
\text { for } p<0.01, * * \text { for } p<0.05 \text { and * for } p<0.1\end{array}$} \\
\hline
\end{tabular}

We fail to reject the null that that the coefficient of lagged EDI is different from zero when using the Gini or the Top1\% measure. However, lagged EDI is found to be positively associated with Top $10 \%$ measure at 10 percent significance level. Given the underestimate of total EDI expenditures inherent in the C2ER data, we would expect the estimates using C2ER data to be downwardly biased. More exploration is needed to tease out differences in the treatment of different sources of EDI spending categories.

\section{CONCLUSION AND DISCUSSION}

This paper presents a normative argument that a more equal distribution of income is a desirable policy goal. EDI are used extensively despite the inconclusive evidence regarding whether such strategies achieve economic growth and development goals. If EDI do not generate growth, then there is the potential that such programs redistribute income among taxpayers and EDI beneficiaries. A reverse-Robin-Hood-effect could result if EDI redistribute income from those below the highest group to the highest income group. Drawing from Subsidy Tracker data provided by Good Jobs First, panel regression estimates suggest that EDI spending is linked with widening income inequality as measured by the Gini coefficient and an increase in the concentration of income for the Top1\% and Top $10 \%$ income groups. Such results are consistent with a reverseRobin-Hood-effect.

There are important caveats worth noting. The Subsidy Tracker data has limitations, especially in its inability to distinguish between unreported incentives and the absence of incentives. For this reason, extensions of this work using revised Subsidy Tracker data as well as alternative databases on incentives would be valuable. For example, Bartik's (2017) new simulation database is worth exploring. 
Another limitation of the Subsidy Tracker data is that it reports multi-period EDI awards as an aggregate amount in a single year. To address this, empirical models might use program evaluation approaches which look at pre- and post-period trends in inequality measures relative to EDI program announcements. Further, exploring the complex nature of the state tax and spending environment and the impact of national and global business cycles are also viable avenues for future work. Finally, it would be useful to consider other portions of the income distribution besides the top income shares. For instance, it would be useful to investigate heterogeneous impacts for the poor and the middle income groups and to further dissect impacts on the lower tail of the income distribution. Such extensions are left for future work.

\section{REFERENCES}

Amos, Orley M. (1991) “An Inquiry into the Causes of Increasing Regional Income Inequality in the United States,” Review of Regional Studies, 21, 1-12.

Arneson, R. (2013) “Egalitarianism” in Edward N. Zalta (ed.) The Stanford Encyclopedia of Philosophy. Stanford University, California.

Bartik, Timothy J. (2017) A New Panel Database on Business Incentives for Economic Development Offered by State and Local Governments in the United States. Pew Charitable Trusts.

Bartik, Timothy J. and G. Erickcek. (2012) "Simulating the Effects of Michigan's MEGA Tax Credit Program on Job Creation and Fiscal benefits,” Upjohn Institute Working Paper 12185: Kalamazoo, Michigan.

Bonica, Adam, Nolan McCarty, Keith T. Poole, and Howard Rosenthal. (2013) "Why hasn't Democracy Slowed Rising Inequality?,” Journal of Economic Perspectives, 2, 103-124.

Bastagli, Francesca, David Coady, and Sanjeev Gupta. (2012) "Income Inequality and Fiscal Policy,” IMF Staff Discussion Note, SDN/12/08.

Bourguignon, François. (2015) The Globalization of Inequality. Princeton University Press: Princeton, New Jersey and Woodstock, Oxfordshire.

Brem, Natalie, Gary Durden, and Patricia Gaynor. (1989) “The Effect of Government Employment on Income Inequality Overall and in the South: Evidence from Congressional District Data,” Review of Regional Studies, 19, 40-47.

Diamond, Peter A. (2016) “Addressing the Forces Driving Inequality in the United States," Contemporary Economic Policy, 34, 403-411.

Dewar, Margaret E., and B. Hagenlocker. (1996) "Getting to the Bottom Line on Low-Interest Loans to Business: An Evaluation of Minnesota's Small Cities Economic Development Program.” Regional Studies, 30, 41-54.

Drutman, Lee. (2015) The Business of America is Lobbying: How Corporation Became Politicized and Politics Became More Corporate. Oxford University Press: Oxford, UK.

Ellis, Stephen E. and Cynthia L. Rogers. (2000) "Local Economic Development as a Prisoners' Dilemma: The Role of Business Climate,” Review of Regional Studies, 30, 315-330.

Felix, R. Alison, and James R. Hines. (2013) "Who Offers Tax-based Business Development Incentives?,” Journal of Urban Economics, 75, 80-91. 
Florida, Richard. (2014) "Mapping Three Decades of Rising Income Inequality, State by State,” CityLab, The Atlantic, Accessed on March 12.

Frank, Mark W. (2009) "Inequality and Growth in the United States: Evidence from a New Statelevel Panel of Income Inequality Measures,” Economic Inquiry, 47, 55-68.

U.S. State-Level Income Inequality Data. Available online at http://www.shsu.edu/eco_mwf/inequality.html.

Gilens, Martin. (2012) Affluence and Influence: Economic Inequality and Political Power in America. Princeton University Press: Princeton, New Jersey.

Goetz, Stephan J., Mark D. Partridge, Dan S. Rickman, and Shibalee Majumdar. (2011) "Sharing the Gains of Local Economic Growth: Race-to-the-top Versus Race-to-the-bottom Economic Development,” Environment and Planning C, 29, 428-456.

Good Jobs First. (2013) "Subsidy Tracker.” Available online at http://www.goodjobsfirst.org/subsidytracker.

Hasanov, Fuad, and Oded Izraeli. (2011) "Income Inequality, Economic Growth, and the Distribution of Income Gains: Evidence from the U.S. States,” Journal of Regional Science, 51, 518-539.

Hirasuna, Donald, and Glen C. Pulver. (1989) “The Income Effects of Public Subsidies to Traded Services,” Review of Regional Studies, 28, 43-64.

Hirsch, Barry T. and David A. Macpherson. (2003) "Union Membership and Coverage Database from the Current Population Survey: Note.” Industrial and Labor Relations Review, 56, 349-54.

. Union Membership and Earnings Data Book: Compilations from the current Population Survey. Bureau of National Affairs: Washington, D.C. Annual.

Jansa, Joshua and Virginia H. Gray. (2017) “Captured Development: Industry Influence and State Economic Development Subsidies in the Great Recession Era.” Economic Development Quarterly, 31, 50-64.

Kant, Immanuel. (1964) Groundwork of the Metaphysic of Morals. trans. H.J. Paton. Harper and Row: New York.

Kenyon, Daphne A, Adam H. Langley, and Bethany P. Paquin. (2012) "Property Tax Incentive Pitfalls,” National Tax Journal, 65, 1011-1022.

Kim, D. H., H.C. Huang, and S.C. Lin. (2011) “Kuznets Hypothesis in a Panel of States," Contemporary Economic Policy, 29, 250-260.

Leight, E. H. (2010) The Relationships Between Inequality, Economic Growth, and Political Control: Explorations Using US State-level Panel Data, 1969-2005. Honors Thesis, Wesleyan University.

Lynch, Devon, and Jeffrey Zax. (2011) "Incidence and Substitution in Enterprise Zone Programs: The Case of Colorado,” Public Finance Review, 39, 226-255.

Mattera, Philip. (2014) "Subsidizing the Corporate One Percent: Subsidy Tracker 2.0 Reveals BigBusiness Dominance of State and Local Development Incentives,”. Available online at 
http://www.goodjobsfirst.org/sites/default/files/docs/pdf/subsidizingthecorporateoneperce nt.pdf.

Mattera,Philip, Kasia Tarczynska, and Greg LeRoy. (2014) “Tax Breaks and Inequality: Enriching Billionaires and Low-Road Employers in the Name of Economic Development,” Available at http://www.goodjobsfirst.org/sites/default/files/docs/pdf/taxbreaksandinequality.pdf.

Mitchell, Matthew. (2014) The Pathology of Privilege: The Economic Consequences of Government Favoritism, $2^{\text {nd }}$ printing. Mercatus Center, George Mason University: Arlington, Virginia.

Niño-Zarazúa, M., L. Roope, F. and Tarp. (2016) “Global Inequality: Relatively Lower, Absolutely Higher,” The Review of Income and Wealth, 63, 661-684.

Nozick, Robert. (1974) Anarchy, State, and Utopia. Basic Books, Inc.: New York.

Olfert, Rose. (2016) “Regional Inequality and Decentralize Governance: Canada’s Provinces.” Review of Regional Studies, 46, 201-222.

Patrick, Carlianne. E. (2014a) “Does Increasing Available Non-Tax Economic Development Incentives Result in More Jobs?,” National Tax Journal, 67, 351-386. . (2014b) “The Economic Development Incentives Game: An Imperfect Information, Heterogeneous Communities Approach,” Annals of Regional Science, 53, 137-156.

Partridge, Mark D. and Dan Rickman. (2003) "Do We Know Economic Development When We See It?,” Review of Regional Studies, 33, 17-39.

- (2005) "Persistent High-Poverty in Nonmetropolitan America: Can Economic Development Help?,” International Regional Science Review, 28, 415-440.

. (2006) “The Geography of American Poverty: Is there a Role for Place-Based Policies?,” W.E.Upjohn Institute for Employment Research: Kalamozoo, Michigan.

Piketty, Thomas, Emmanuel Saez, and Gabriel Zucman. (2006) "Distributional National Accounts: Methods and Estimates for the United States,” NBER Working Paper 22945: Cambridge, Massachusetts.

Persky, Joseph, Daniel Felsenstein, and Virginia Carlson. (2004) Does “Trickle Down” Work? Economic Development Strategies and Job Chains in Local Labor Markets. W.E. Upjohn Institute for Employment Research: Kalamazoo, Michigan.

Peters, Alan and Peter Fisher. (2004) “The Failures of Economic Development Incentives," Journal of the American Planning Association, 70, 27-37.

Pew Center on the States. (2012) Evidence Counts: Evaluating State Incentives for Jobs and Growth. Pew Charitable Trusts: Washington, D.C.

Pew Charitable Trusts. (2017) How States Are Improving Tax Incentives for Jobs and Growth: A National Assessment of Evaluation Practices. Pew Charitable Trusts : Washington, D.C.

Price, Carter C. and Heather Boushey. (2014) How Are Economic Inequality and Growth Connected? A Review of Recent Research. Washington Center for Equitable Growth.

Schmidtz, David. (2015) Rational Choice and Moral Agency. Princeton University Press: New Jersey.

c Southern Regional Science Association 2018. 
Scott, Robert E. (2015) "Manufacturing Job Loss: Trade, Not Productivity, Is the Culprit," Economic Policy Institute Issue Brief \#402.

Sen, Amarta. (2015) “The Moral Standing of the Market,” Social Philosophy and Policy, 2, 1-19.

Shuai, Xiaobing. (2015) “Do Economic Development Efforts Benefit All? Business Attraction and Income Inequality,” Review of Regional Studies, 45, 35-56.

Sommeiller, Estelle, Mark Price, and Ellis Wazeter. (2016) Income Inequality in the U.S. by State, Metropolitan Area, and County, Economic Policy Institute.

Story, Louise, Tiff Fehr, and Derek Watkins (2012) “United States of Subsidies,” Available online in December at http://www.nytimes.com/interactive/2012/12/01/us/governmentincentives.html.

Tiebout, Charles M. (1956) “A Pure Theory of Local Expenditures,” Journal of Political Economy, 64, 416-424.

Tullock, Gordon. (1971) “Public Decisions as Public Goods,” Journal of Political Economy, 79, 913-918.

Wang, Jia. (2016) “Do Economic Development Incentives Crowd Out Public Expenditures in U.S. States?,” BE Journal of Economic Analysis \& Policy, 16, 513-538.

. (2017) "Strategic Interaction and Economic Development Incentives Policy: Evidence from U.S. States.” Unpublished Paper.

Williams, Sean. (2014) What Do the States Tell Us About Rising Top Income Shares? Doctoral Dissertation: Hubert H. Humphrey School of Public Affairs.

Williams, Walter. (1996) “The Argument for Free Markets: Morality vs. Efficiency,” Cato Journal, 15, 179-189.

(c) Southern Regional Science Association 2018. 